\title{
Amauroderma (Ganodermataceae, Polyporales) - bioactive compounds, beneficial properties and two new records from Laos
}

\author{
Hapuarachchi KK ${ }^{1,2,3}$, Karunarathna $\mathrm{SC}^{4}$, Phengsintham $\mathbf{P}^{5}$, Kakumyan $\mathbf{P}^{2}$, \\ Hyde $\mathrm{KD}^{1,2,4}$ and Wen $\mathrm{TC}^{3}$
}

\author{
${ }^{1}$ Center of Excellence in Fungal Research, Mae Fah Luang University, Chiang Rai 57100, Thailand \\ ${ }^{2}$ School of Science, Mae Fah Luang University, Chiang Rai 57100, Thailand \\ ${ }^{3}$ The Engineering Research Center of Southwest Bio-Pharmaceutical Resource Ministry of Education, Guizhou \\ University, Guiyang 550025, Guizhou Province, China \\ ${ }^{4}$ Key Laboratory for Plant Diversity and Biogeography of East Asia, Kunming Institute of Botany, Chinese Academy of \\ Sciences, 132 Lanhei Road, Kunming 650201, China \\ ${ }^{5}$ National University of Laos, Dongdok, Vientiane, Vientiane, Lao PDR
}

Hapuarachchi KK, Karunarathna SC, Phengsintham P, Kakumyan P, Hyde KD, Wen TC 2018 Amauroderma (Ganodermataceae, Polyporales) - bioactive compounds, beneficial properties and two new records from Laos. Asian Journal of Mycology 1(1), 121-136, Doi 10.5943/ajom/1/1/10

\begin{abstract}
Species of Ganodermataceae have been widely used as traditional medicines in Asia over many centuries. Ganoderma and Amauroderma are widely researched, owing to their beneficial medicinal properties. We surveyed species of Amauroderma in the Greater Mekong Subregion countries; China, Laos, Myanmar, Thailand and Vietnam. In this paper, we introduce two new records of Amauroderma from Laos; Amauroderma pressuii based on morphology and A. rugosum based on both morphology and molecular phylogenetic evidence. The collected species are described with coloured photographs and illustrations and compared with similar taxa. We also provide a phylogeny for Amauroderma based on ITS and LSU sequence data and the taxonomic status of the species is briefly discussed. In addition, we reviewed the bioactive compounds and beneficial properties of Amauroderma.
\end{abstract}

Key words - Medicinal properties - Morphology - Phylogeny - Two new records

\section{Introduction}

Ganodermataceae is a large family of Polypores with seven accepted genera: Amauroderma, Foraminispora, Furtadoa, Ganoderma, Haddowia, Humphreya and Polyporopsis (Richter et al. 2015, Costa-Rezende et al. 2017). The genus Amauroderma Murrill was described in 1905 based on Fomes regulicolor Cooke (1886) and typified by Amauroderma regulicolor (Berk. ex Cooke) Murrill (= A. schomburgkii) from Cuba (Torrend 1920). Torrend (1920) worked on the genus in South America based mainly on spore shape (globose or oblong, never truncate) and the presence of a stipe (usually dull, like the pilear surface) and published 28 species of Amauroderma placed within three sections. Amauroderma was carefully revised by Furtado (1981) and recognized 27 species. This genus has a tropical and subtropical distribution with the main centre of diversity in the Neotropics (Ryvarden 2004). Amauroderma species are usually found in associated with dead wood or roots of living or dead trees typically emerging from the ground and the mycelial phase is connected to the roots of living or dead trees which causes white rot (Furtado 1981, Ryvarden 
2004). There are 135 epithets listed in Index Fungorum (2018). The members of Amauroderma varies from stipitate to sessile basidiomata with a variably laccate or dull pileus, a trimitic hyphal system and ellipsoid, subglobose to globose bitunicate basidiospores with a smooth, semireticulate, honeycomb or asperulate to verrucose inner wall (Furtado 1981, Ryvarden 2004, GomesSilva et al. 2015, Li \& Yuan 2015). Macroscopically, Amauroderma shares similarities with Ganoderma P. Karst. in the similar basidiocarp shape of the central or lateral stipe and laccate or dull surface. Ganoderma can be separated from Amauroderma by its distinctly truncate basidiospores, and most Ganoderma species grow on dead wood, while most Amauroderma species grow in the ground from buried roots/woods (Ryvarden 2004, Hapuarachchi et al. 2015). It was shown that Amauroderma is a non-monophyletic taxon based on comprehensive morphological and phylogenetic analyses by some researchers in Brazil (Gomes-Silva et al. 2015, Costa-Rezende et al. 2016).

Amauroderma species are regarded as economically valuable because of their important medicinal properties and pathogenicity (Dai et al. 2007, 2009, Jiao et al. 2013, Chan et al. 2013). Taxonomic studies of Amauroderma in Asia have been carried out over many years by various researchers (Teng 1936, Zhao et al. 1979, Zhao \& Zhang 1987, Li \& Yuan 2015, Song et al. 2016). Twenty species have been recorded in China (Zhao \& Zhang 2000), but among these, only six have been confirmed as Amauroderma based on both morphological characters and phylogenetic analyses: A. austrosinense J.D. Zhao \& L.W. Hsu, A. concentricum Song, Xiao L. He \& B.K. Cui, A. perplexum Corner, A. rugosum (Blume \& T. Nees) Torrend, A. subresinosum (Murrill) Corner and A. yunnanense J.D. Zhao \& X.Q. Zhang (Li \& Yuan 2015), while the other Amauroderma species recorded from China have not been fully studied yet. Furthermore, members of this genus have been subsequently recorded from the Greater Mekong Subregion countries such as Thailand (Chandrasrikul et al. 2011), Myanmar (Thaung 2007) and Vietnam (Quang et al. 2011). Here, we report on $A$. pressuii and A. rugosum as new records from Laos based on morphology and both morphology and molecular data, respectively. We provide a phylogeny for the Amauroderma based on combined ITS and LSU analyses. Moreover, we present and discuss experimental evidences in connection with Amauroderma and its beneficial medicinal properties.

\section{Materials \& Methods}

Samples of Amauroderma were collected on July 2016 and June 2017 from Laos and dealt with as in Cao et al. (2012). The materials were deposited at Guizhou University (GACP) and Mae Fah Luang University (MFLU) herbaria.

\section{Morphological characteristics examination}

Macro-morphological characteristics were described based on fresh material, and on the photographs provided here. Colour codes (e.g. 5B5) are from Kornerup \& Wanscher (1978). Specimens were dried and placed separately in plastic bags. For micro-morphological observations, basidiomes were examined under a stereo dissecting microscope (Motic SMZ 168 series) and sections were cut with a razor blade, mounted in $5 \% \mathrm{KOH}$, and then observed, measured and illustrated under a compound microscope (Nikon ECLIPSE 80i) equipped with a camera (Canon 600D). Measurements were made using Tarosoft (R) Image Frame Work v. 0.9.7. At least 20 basidiospores were measured from each mature specimen except for very scanty materials. The basidiospore size was measured both with and without the myxosporium, but only spore sizes with myxosporium were used for comparisons. Basidiospore dimensions are given as $(a-) b-c-d(-e)$, where a represents the minimum, $b$ (mean average-standard deviation), $c$ the average, $d$ (mean average+standard deviation) and e the maximum. $Q$, the length/width ratio (L/W) of a spore in side view and $Q m$ is the average, smallest and largest $Q$ values given as $Q$. Pellis sections were taken from the mature pileus portion and mounted in Melzer's reagent for observation. The Facesoffungi number is provided as explained in Jayasiri et al. (2015). 


\section{DNA extraction, PCR and sequencing}

Dried samples of basidiomes were used to extract genomic DNA. Genomic DNA was extracted using an EZgene TM Fungal gDNA Kit (Biomiga, CA, USA) according to the manufacturer instructions. DNA concentrations were estimated visually in agarose gel by comparing band intensity with a DNA ladder $1 \mathrm{~Kb}$ (Invitrogen Biotech). Reaction mixtures (50 $\mu \mathrm{l}$ ) contained $2 \mu \mathrm{l}$ template DNA (ca. $10 \mathrm{ng}$ ), $19 \mu \mathrm{l}$ distilled water, and $2 \mu 1(10 \mu \mathrm{M})$ of each primer and $25 \mu \mathrm{l} 2 \mathrm{x}$ BenchTopTM Taq Master Mix (Biomigas). Amplification conditions were 40 cycles of $95{ }^{\circ} \mathrm{C}$ for $30 \mathrm{~s}, 59{ }^{\circ} \mathrm{C}$ for $30 \mathrm{~s}$ and $72{ }^{\circ} \mathrm{C}$ for $1 \mathrm{~min}$, followed by a final extension at $72{ }^{\circ} \mathrm{C}$ for 10 min for all DNA fragments. The ITS rDNA regions were amplified using the universal primer pair ITS4 and ITS5 (White et al. 1990). Amplified PCR products were verified by 1\% agarose gel electrophoresis stained with ethidium bromide in 1x TBE. The PCR products were sequenced by SinoGenoMax Co., Ltd (Beijing).

\section{Sequence alignment and phylogenetic analysis}

The taxa information and GenBank accession numbers used in the molecular phylogenetic analyses are listed in Table 1. The quality of the newly obtained sequences from the Amauroderma specimens was checked by observing the chromatogram with BioEdit (Hall 1999) and by examining BLAST search results according to Nilsson et al. (2012). The BLAST search was also used to retrieve sequences from the closest matching taxa in Amauroderma. Forty-two nucleotide sequences representing 22 species of Amauroderma from Asia, Australia and South America were retrieved from GenBank. Those sequences and five newly generated sequences were aligned using MAFFT v. $7.309 \quad$ (Katoh \& Standley 2013) online at http://mafft.cbrc.jp/alignment/server/index.html, and the alignment was improved manually where necessary using Bioedit. Maximum likelihood (ML) analysis was performed using RAxML-HPC2 (Stamatakis 2014) on the CIPRES Science Gateway V. 3.3 (Miller \& Blair 2009), with default settings except the number of bootstrap replicates was set to 1,000. For Bayesian (BY) analysis, GTR $+\mathrm{I}+\mathrm{G}$ model of evolution was selected with MrModeltest 2.2 (Nylander 2004) as the best-fit model. BY analyses were conducted with two runs of six simultaneous Markov chains and trees were sampled every 100th generation. The analyses were stopped after 5,000,000 generations when the average standard deviation of split frequencies was below 0.01 . The convergence of the runs was checked using TRACER v1.6 (Rambaut et al. 2013). The first 25\% of the resulting trees were discarded as burn-in, and PP were calculated from the remaining sampled trees. In both ML and BY analyses, Tomophagus colossus was selected as the outgroup taxon. ML bootstrap values and Bayesian posterior probabilities greater than or equal to $70 \%$ and 0.95 , respectively, were considered as significant support. The phylogenetic tree was visualized with FigTree version 1.4.0 (Rambaut 2012) available at http://tree.bio.ed.ac.uk/software/figtree/.

Table 1 Sequences used in the phylogenetic analysis

\begin{tabular}{|c|c|c|c|c|c|}
\hline Species & $\begin{array}{l}\text { Voucher/ } \\
\text { Strain }\end{array}$ & Origin & ITS & $\mathbf{L S U}$ & References \\
\hline $\begin{array}{l}\text { Amauroderma } \\
\text { aurantiacum }\end{array}$ & FLOR 52205 & Brazil & KR816510 & KU315205 & $\begin{array}{l}\text { Costa-Rezende et al. } \\
2016\end{array}$ \\
\hline A. aurantiacum & URM 78847 & Brazil & JX310840 & JX310840 & $\begin{array}{l}\text { Gomes-Silva et al. } \\
2010\end{array}$ \\
\hline A. austrosinense & Cui 13618 & China & KU219973 & KU219996 & Song et al. 2016 \\
\hline A. calcigenum & URM 83864 & Brazil & JX982565 & JX982565 & $\begin{array}{l}\text { Gomes-Silva et al. } \\
2010\end{array}$ \\
\hline A. calcigenum & URM 86847 & Brazil & КT006601 & KT006601 & $\begin{array}{l}\text { Gomes-Silva et al. } \\
2010\end{array}$ \\
\hline A. calcitum & FLOR 50931 & Brazil & KR816528 & KR816528 & $\begin{array}{l}\text { Costa-Rezende et al. } \\
2016\end{array}$ \\
\hline
\end{tabular}


Table 1 Continued.

\begin{tabular}{|c|c|c|c|c|c|}
\hline Species & $\begin{array}{l}\text { Voucher/ } \\
\text { Strain } \\
\end{array}$ & Origin & ITS & LSU & References \\
\hline A. calcitum & FLOR 52230 & Brazil & KR816529 & - & $\begin{array}{l}\text { Costa-Rezende et al. } \\
2016\end{array}$ \\
\hline A. camerarium & FLOR 52169 & Brazil & KR816523 & KR816523 & $\begin{array}{l}\text { Costa-Rezende et al. } \\
2016\end{array}$ \\
\hline A. concentricum & Cui 12644 & $\begin{array}{l}\text { Sichuan, } \\
\text { China }\end{array}$ & KU219974 & KU219997 & Song et al. 2016 \\
\hline A. concentricum & Cui 12648 & $\begin{array}{l}\text { Sichuan, } \\
\text { China }\end{array}$ & KU219975 & KU219998 & Song et al. 2016 \\
\hline A. elegantissimum & URM 82787 & Brazil & JX310843 & KT006616 & $\begin{array}{l}\text { Gomes-Silva et al. } \\
2010\end{array}$ \\
\hline A. elegantissimum & URM 82789 & Brazil & JX310844 & KT006617 & $\begin{array}{l}\text { Gomes-Silva et al. } \\
2010\end{array}$ \\
\hline A. exile & URM 82794 & Brazil & JX310845 & JX310845 & $\begin{array}{l}\text { Gomes-Silva et al. } \\
2010\end{array}$ \\
\hline A. floriformum & URM 83250 & Brazil & JX310846 & JX310846 & $\begin{array}{l}\text { Gomes-Silva et al. } \\
2010\end{array}$ \\
\hline A. intermedium & FLOR 52246 & Brazil & KR816524 & KU315208 & $\begin{array}{l}\text { Costa-Rezende et al. } \\
2016\end{array}$ \\
\hline A. intermedium & FLOR 52248 & Brazil & KR816527 & KU315209 & $\begin{array}{l}\text { Costa-Rezende et al. } \\
2016\end{array}$ \\
\hline $\begin{array}{l}\text { A. } \\
\text { laccatostipitatum }\end{array}$ & HFSL (ACGS7) & Brazil & KT006602 & - & $\begin{array}{l}\text { Gomes-Silva et al. } \\
2010\end{array}$ \\
\hline $\begin{array}{l}\text { A. } \\
\text { laccatostipitatum }\end{array}$ & URM 83238 & Brazil & JX310847 & JX310847 & $\begin{array}{l}\text { Gomes-Silva et al. } \\
2010\end{array}$ \\
\hline A. omphalodes & MG (AS592) & Brazil & KT006603 & - & $\begin{array}{l}\text { Gomes-Silva et al. } \\
2010\end{array}$ \\
\hline A. omphalodes & URM 84236 & Brazil & KT006604 & - & $\begin{array}{l}\text { Gomes-Silva et al. } \\
2010\end{array}$ \\
\hline A. partitum & URM 82884 & Brazil & JX310851 & - & $\begin{array}{l}\text { Gomes-Silva et al. } \\
2010\end{array}$ \\
\hline A. partitum & URM 83039 & Brazil & JX310852 & - & $\begin{array}{l}\text { Gomes-Silva et al. } \\
2010\end{array}$ \\
\hline A. perplexum & Cui 6496 & $\begin{array}{l}\text { Hainan, } \\
\text { China }\end{array}$ & KJ531650 & KU220001 & Li \& Yuan 2015 \\
\hline A. perplexum & Dai 10811 & $\begin{array}{l}\text { Hainan, } \\
\text { China }\end{array}$ & KJ531651 & KU220002 & Li \& Yuan 2015 \\
\hline A. praetervisum & REC 18707 & Brazil & JX310855 & - & $\begin{array}{l}\text { Gomes-Silva et al. } \\
2010\end{array}$ \\
\hline A. praetervisum & URM 84223 & Brazil & KT006605 & - & $\begin{array}{l}\text { Gomes-Silva et al. } \\
2010\end{array}$ \\
\hline A. rude & CANB 643174 & Australia & KU315197 & KU315197 & $\begin{array}{l}\text { Costa-Rezende et al. } \\
2016\end{array}$ \\
\hline A. rugosum & $\begin{array}{l}\text { GACP1406212 } \\
0\end{array}$ & Thailand & MK077648 & - & This study \\
\hline A. rugosum & $\begin{array}{l}\text { GACP1607271 } \\
4\end{array}$ & Laos & MK077647 & - & This study \\
\hline A. rugosum & $\begin{array}{l}\text { GACP1607270 } \\
7\end{array}$ & Laos & MK077646 & - & This study \\
\hline A. rugosum & $\begin{array}{l}\text { GACP } \\
14081118\end{array}$ & $\begin{array}{l}\text { Hainan, } \\
\text { China }\end{array}$ & MK077644 & - & This study \\
\hline A. rugosum & $\begin{array}{l}\text { GACP1408152 } \\
2\end{array}$ & $\begin{array}{l}\text { Hainan, } \\
\text { China }\end{array}$ & MK077645 & - & This study \\
\hline
\end{tabular}


Table 1 Continued.

\begin{tabular}{|c|c|c|c|c|c|}
\hline Species & $\begin{array}{l}\text { Voucher/ } \\
\text { Strain } \\
\end{array}$ & Origin & ITS & LSU & References \\
\hline A. rugosum & Dai 10746 & China & KU219981 & - & Song et al. 2016 \\
\hline A. schomburgkii & URM 84228 & Brazil & КT006608 & - & $\begin{array}{l}\text { Gomes-Silva et al. } \\
2010\end{array}$ \\
\hline A. schomburgkii & URM 84254 & Brazil & KT006611 & - & $\begin{array}{l}\text { Gomes-Silva et al. } \\
2010\end{array}$ \\
\hline A. sessile & URM83905 & Brazil & JX982570 & - & $\begin{array}{l}\text { Gomes-Silva et al. } \\
2010\end{array}$ \\
\hline A. sprucei & FLOR 52184 & Brazil & KU315201 & - & $\begin{array}{l}\text { Costa-Rezende et al. } \\
2016\end{array}$ \\
\hline A. sprucei & FLOR 52191 & Brazil & KU315200 & KU315216 & $\begin{array}{l}\text { Costa-Rezende et al. } \\
2016\end{array}$ \\
\hline A. subsessile & URM 83239 & Brazil & JX310860 & JX310860 & $\begin{array}{l}\text { Gomes-Silva et al. } \\
2010\end{array}$ \\
\hline A. subsessile & URM 83905 & Brazil & JX982570 & - & $\begin{array}{l}\text { Gomes-Silva et al. } \\
2010\end{array}$ \\
\hline A. yunnanense & Cui 7974 & $\begin{array}{l}\text { Yunnan, } \\
\text { China }\end{array}$ & KJ531653 & KU220013 & Li \& Yuan 2015 \\
\hline A. yunnanense & Dai 13021 & $\begin{array}{l}\text { Yunnan, } \\
\text { China }\end{array}$ & KJ531654 & - & Li \& Yuan 2015 \\
\hline $\begin{array}{l}\text { Tomophagus } \\
\text { colossus (Fr.) } \\
\text { Murrill }\end{array}$ & $\mathrm{TC} 02$ & China & KJ143923 & - & Zhou et al. 2015 \\
\hline
\end{tabular}

\section{Results and Discussion}

\section{Phylogeny}

The tree topologies obtained from ML and BY were identical. Therefore, only the ML tree is shown in Fig. 1. Two major clades; South American and South East Asian, were identified in Amauroderma (Fig. 1). Amauroderma rugosum sequences obtained from China (GACP14081118 and GACP14080952), Thailand (GACP1406212) and Laos (GACP16072714 and GACP14081522) clustered in a well-supported clade forming monophyletic group ( $\mathrm{BS}=100 \%$; $\mathrm{BPP}=1.0)$ (Fig. 1). Given the phylogenetic results obtained herein where our new collections are found in a clade with A. rugosum, we believe that it would taxonomically be more appropriate to establish them as new records of $A$. rugosum. Furthermore, the deep nodes are not supported well in the tree, but this does not affect the final conclusions of the study. However, to obtain a better view of evolution of the genus, a phylogeny with more genes, and in particular single-copy nuclear genes such as tef1 or rpb2 would be recommended.

\section{Taxonomy}

Amauroderma P. Karst., 1881, Rev. Mycol. (Toulouse) 3, p. 17.

= Amauroderma (Pat.) Torrend, Brotéria, sér. Bot. 18: 121 (1920)

= Ganoderma sect. Amauroderma Pat., Bull. Soc. mycol. Fr. 5(2, 3): 75 (1889)

= Lazulinospora Burds. \& M.J. Larsen, Mycologia 66(1): 97 (1974)

= Magoderna Steyaert, Persoonia 7(1): 111 (1972)

= Whitfordia Murrill, Bull. Torrey bot. Club 35: 407 (1908)

Description (from Ryvarden 2004)

Basidiocarps annual or reviving for a second season, centrally-laterally stipitate, solitary or in small groups with several fused pilei, consistency coriaceous, corky to woody hard, seldom brittle. 
Pileus round, reniform to fan-shaped, concave, umbilicate to strongly infundibuliform, upper surface in varying colours from white, ochraceous, brown to almost black, finely tomentose to glabrous, dull to glossy with a distinct cortex or cuticle, often concentrically zoned and radially wrinkled, stipe rather thin and long, finely tomentose to glabrous, pore surface whitish to ochraceous when fresh, darkens when dry to brownish colours, pores round to angular and entire, large to small, tubes seldom stratified, context white, ochraceous to dark brown, cystidia absent, hyphal system dimitic, generative hyphae with clamps hyaline and thin-walled, skeletal hyphae arboriform to more rarely unbranched, hyaline to brown, those being hyaline often dextrinoid or without reaction in Melzer's reagent, basidia bladder-like with 4 large curved sterigmata, basidiospores hyaline to pale yellow, sub-globose to cylindrical, dextrinoid to non-dextrinoid, bitunicate with the inner wall finely asperulate or very rarely smooth.

Type species: Amauroderma regulicolor (Berk. ex Cooke) Murrill (= Amauroderma schomburgkii)

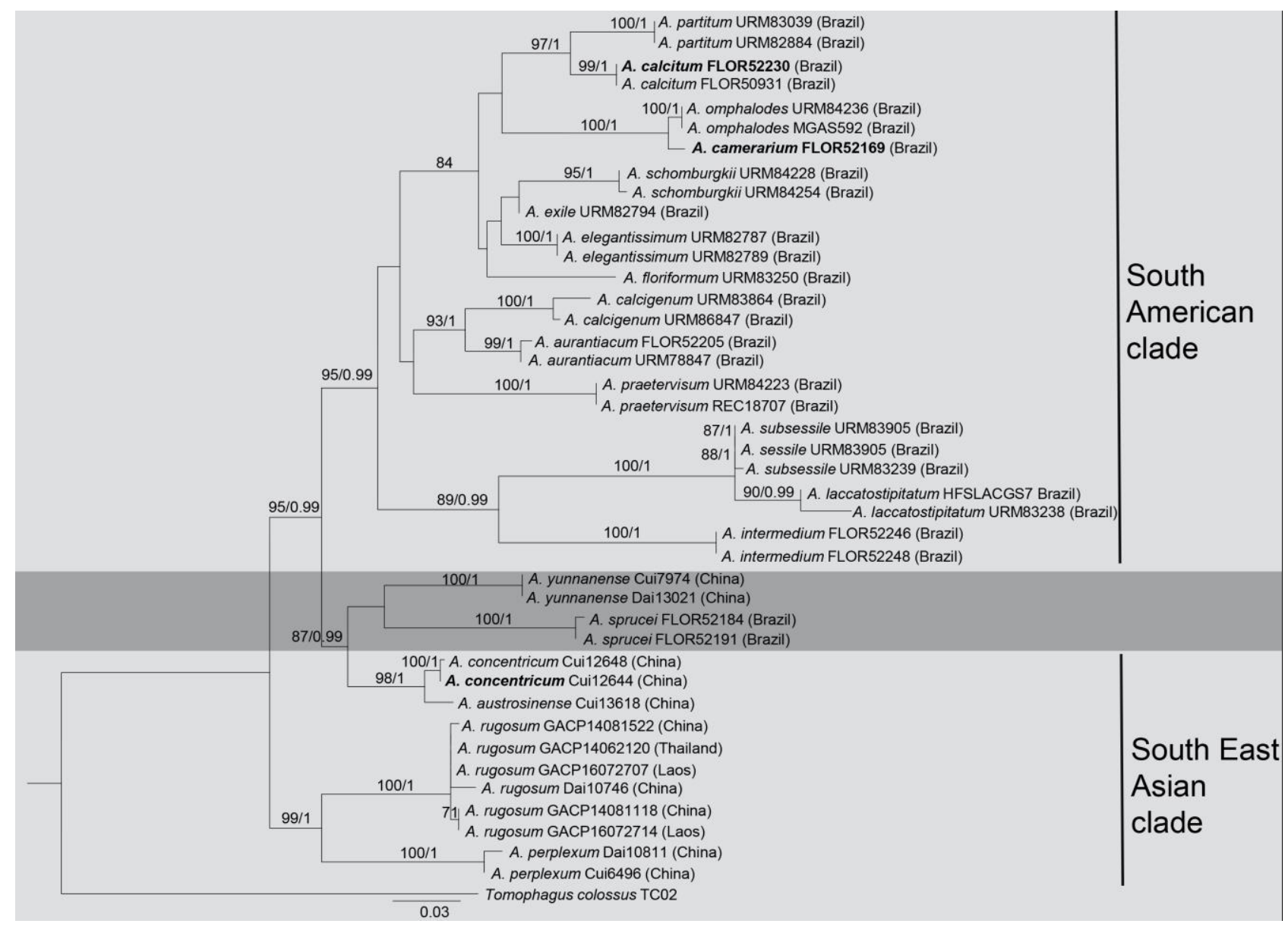

Fig. 1 - Phylogram generated from maximum likelihood analysis of ITS and LSU sequence data. Bootstrap support values for maximum likelihood, greater than $70 \%$ and Posterior Probabilities from Bayesian Inference $\geq 0.95$ are given above branches. The tree is rooted with Tomophagus colossus. The strain numbers and the countries of origin are mentioned after the species. Type species are indicated in black bold.

Amauroderma preussii (Henn.) Steyaert, Persoonia 7(1): 107 (1972)

Fig. 2

$\equiv$ Ganoderma preussii Henn. (1891)

(See Index Fungorum for other synonyms)

Facesoffungi number. FoF05185

Basidiome annual, corky, with distinctly contracted base at the center, becoming hard corky to woody hard when dry. Pileus single, $8-12 \mathrm{~cm}$, up to $1 \mathrm{~cm}$ thick at the base, orbicular; upper 
surface brown (6E4) to dark brown (6E5) alternating colour zones, near to margin, weakly laccate to non laccate, concentrically undulate, radially rugose; margin grey $(6 \mathrm{~F} 1)$, wavy, inflexed; lower surface usually brown (6D7). Hymenophore up to $10 \mathrm{~mm}$ long, indistinctly stratose; pores initially brownish orange (5C4), bruising brown (6E8), pores circular or isodiametric, 2-4 per mm. Context $1 \mathrm{~cm}$ thick, triplex, not completely homogeneous in color; lower layer whitish yellow (4A2) to yellow (4A3), corky; middle layer whitish yellow (4A2) to yellow (4A3); fibrous/pithy, composed of coarse loose fibrils; upper layer yellowish brown (6B3), woody. Basidiospores $(\mathrm{n}=25)(8.5) 9.0$ 9.9-10.8(12.1) × (6.7)7.6-8.5-9.5(10.5) $\mu \mathrm{m}\left(Q_{m}=1.1, Q=0.9-1.4\right.$, with myxosporium $) .(\mathrm{n}=25)$ (7.5)7.9-8.6-9.4(10.1) $\times(4.9) 6.2-7.3-8.3(9.9) \mu \mathrm{m}\left(Q_{m}=1.1, Q=0.8-1.6\right.$, without myxosporium), subglobose, bitunicate, with a dark brown (6D8), eusporium bearing echinulae, overlaid by a hyaline myxosporium. Pileipellis a hymeniderm, pale yellow (4A3), streaks near the cutis, a closely-packed palisade, whitish yellow (4A2), clavate terminal elements. Context trimitic; generative hyphae $(\mathrm{n}=30)(0.3-0.9-1.6) \mu \mathrm{m}$ in width, colorless, thin-walled; skeletal hyphae $(\mathrm{n}=$ 30) (1.9-2.4-3.1) $\mu \mathrm{m}$ in width, thick walled, sometimes branched brown (6E4) to greyish brown (6E3); binding hyphae $(\mathrm{n}=30)(0.4-1.4-2.3) \mu \mathrm{m}$ in width, branched, with clamp-connections, brown (6E4) to greyish brown (6E3), frequently branched at apex, intertwined with the skeletal hyphae (Fig. 2).

Habitat - Rotten conifer wood, on the soil near humus rich soil with over heavily rotted litter on the ground, growing up from soil.

Specimens examined - Laos, Xiengkhouang Province, Phoukoud District, Yai village, evergreen forest, $19^{\circ} 58^{\prime} \mathrm{N}-103^{\circ} 00^{\prime} \mathrm{E}$, elev. $1120 \mathrm{~m}$, collection date 27 July 2016, collector P. Phengsintham (GACP16072703, GACP16072833). China, Hainan Province, Jiangfengling Mountain, Coniferous rainforest, $18^{\circ} 44^{\prime} \mathrm{N}-108^{\circ} 51^{\prime} \mathrm{E}$, elev. $550 \mathrm{~m}$, collection date 21 October 2015, collector X.L Wu (GACP WXL15100201).

Notes - Amauroderma preussii was introduced as Ganoderma pressuii by Hennings (1891) from Cameroon. Steyaert (1972) transferred this species to Amauroderma (as A. pressuii). This species is characterized by sub-circular to circular, concentrically undulate pileus with darker concentric shades and spherical basidiospores (Steyaert 1972). Macroscopically, A. preussii is very difficult to distinguish from $A$. oblongisporum and the crust of the pileus of this species is thicker than in $A$. preussii and it is smoother in dry condition (Ryvarden \& Johansen 1980). Furthermore, the pileus of this species is similar to A. wuzshishanense, however the latter has deep funnel-shaped pileus and larger spores (Wu \& Dai 2005). This species has been recorded previously from African countries as a wood decaying species (Steyaert 1972, Ryvarden \& Johansen 1980). It was recorded from various parts of China as a wood inhabiting polypore species (Bi et al. 1993, Wu \& Dai 2005, Dai et al. 2011). Our collections from Laos agree well with description provided by the Ryvarden \& Johansen (1980), Bi et al. (1993), Wu \& Dai (2005) even though we were unable to obtain the DNA. Furthermore, there is not any sequence data available for A. preussii in GenBank

Amauroderma rugosum (Blume \& T. Nees) Torrend Brotéria, sér. bot. 18: 127 (1920) $\quad$ Fig. 3

$\equiv$ Polyporus rugosus Blume \& T. Nees 1826

= Amauroderma amoiense J.D. Zhao \& L.W. Hsu, Acta Mycol. Sinica 2: 164. (1983) = Amauroderma wuzhishanense J.D. Zhao \& X.Q. Zhang, Acta Mycol. Sinica 6: 208. (1987)

(See Index Fungorum for other synonyms)

Facesoffungi number. FoF05186

\section{Sanctioning author:}

Fr.

Basidiome annual, stipitate, weakly laccate, corky. Pileus $2.5-3.6 \times 2.0-2.4 \mathrm{~cm}$, up to $0.5 \mathrm{~cm}$ thick at the base, subreniform, mesopodal; upper surface brownish orange (6C4) to brown (6E8), radially rugose, concentrically sulcate with irregularly ruptured crust, wrinkled towards the edge; 

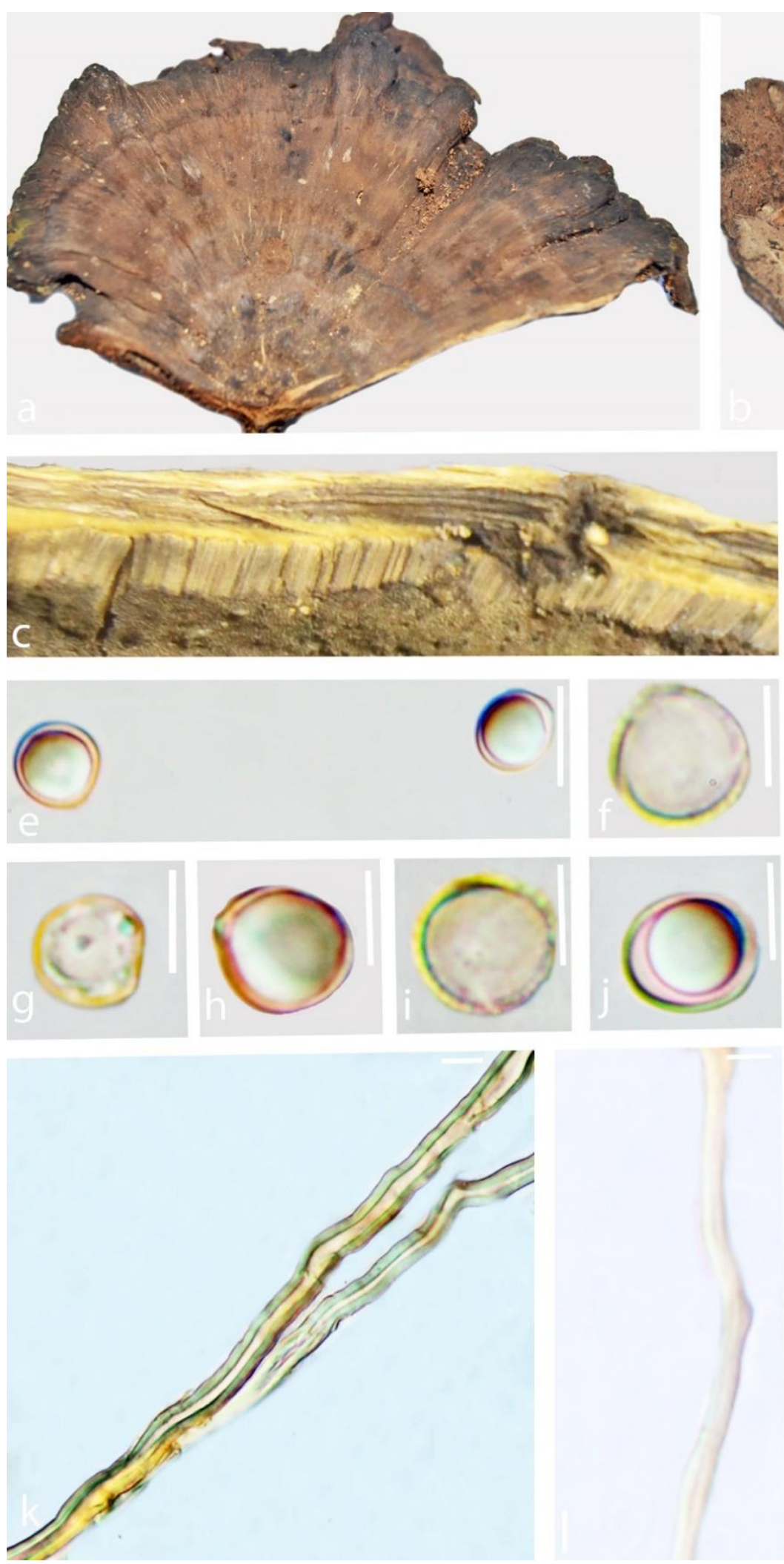
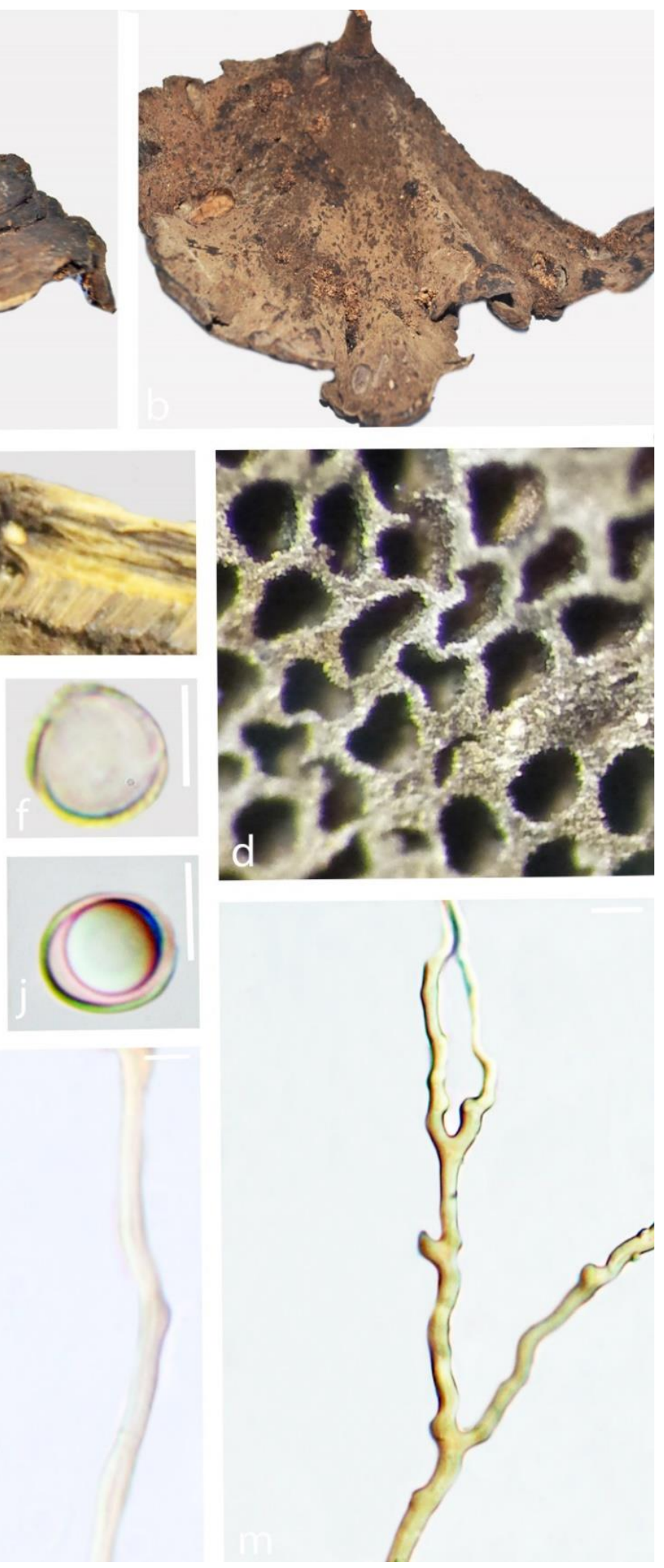

Fig. 2 - Amauroderma preussi (GACP16072703). a Upper surface. b Lower surface. c Pores in the lower surface $(5 \times)$. d Cut surface. e-j Spores $(100 \times)$. k Skeletal hyphae $(100 \times)$. 1 Generative hyphae $(100 \times)$. $\mathrm{m}$ Binding hyphae $(100 \times)$. Scale bars: $\mathrm{e}-\mathrm{j}=10 \mu \mathrm{m}, \mathrm{k}-\mathrm{m}=5 \mu \mathrm{m}$.

margin blunt or wavy, concolorous with the pileus; lower surface greyish orange (5B5). Hymenophore up to $12 \mathrm{~mm}$ long, indistinctly stratose; pores initially brownish orange (5C4), bruising brown (6E8), pores circular, 3-5 per mm. Context up to $8 \mathrm{~mm}$ thick, duplex, dry; upper layer light brown (5D6), fibrous, composed of coarse loose fibrils; lower layer brown (6E8), corky. 
Stipe eccentric, sub cylindrical, concolorous with the pileus, $5 \times 7 \mathrm{~cm}$. Basidiospores $(\mathrm{n}=20)(9.5-$ )10.1-10.7-11.6(11.7-) $\times(-7.7) 7.9-8.5-9.4(-9.6) \mu \mathrm{m}\left(Q_{m}=1.2, Q=1.1-1.4\right.$, with myxosporium $)$. $(7.5-) 8.3-9.3-10.4(-10.6) \times(5.6-) 5.8-6.9-8.0(-8.4) \mu \mathrm{m}\left(Q_{m}=1.2, Q=0.9-1.3\right.$, without myxosporium), subglobose, brownish yellow (5B3), with a brown eusporium, overlaid by a hyaline myxosporium. Pileipellis a hymeniderm, brownish orange (5C4), clavate like cells, dextrinoid. Context trimitic; generative hyphae $(\mathrm{n}=25)(0.5-1.1-2.2) \mu \mathrm{m}$, hyaline, thin-walled with clamp connections, rarely seen; skeletal hyphae $(\mathrm{n}=25)(1.2-2.5-3.5) \mu \mathrm{m}$, thick-walled, nearly solid, sometimes branched, ochre orange white $(5 \mathrm{~A} 2)$; binding hyphae $(\mathrm{n}=20)(0.6-1.7-2.6) \mu \mathrm{m}$, thickwalled, branched, nearly solid, orange white (5A2) (Fig. 3).

Habitat - Rotten conifer wood, in dry dipterocarp forest and in upper mixed deciduous forest, growing up from soil.

Specimens examined - Laos, Xiengkhouang Province, Phoukoud District, Yai village, evergreen forest, $19^{\circ} 58^{\prime} \mathrm{N}-103^{\circ} 00^{\prime} \mathrm{E}$, elev. $1120 \mathrm{~m}$, collection date 27 July 2016, collector P. Phengsintham (GACP16072707, GACP16072714). Savvanakhet province, Phin district Phouxang Hae Protected Area, mixed deciduous forest, $16^{0} 58^{\prime} \mathrm{N}-105^{\circ} 89^{\prime} \mathrm{E}$, elev. $173 \mathrm{~m}$, collection date 23 June 2017, collector P. Phengsintham (GACP17062326, GACP17062328), China, Hainan Province, Jiangfengling Mountain, Coniferous rainforest, $18^{\circ} 44^{\prime} \mathrm{N}-108^{\circ} 51^{\prime} \mathrm{E}$, elev. $550 \mathrm{~m}$, $19^{\circ} 12^{\prime} \mathrm{N} 109^{\circ} 42^{\prime \prime \prime} \mathrm{E}$, collection date 9 August 2014, collector T.C Wen (GACP14080910, GACP14080952, GACP14080929, GACP14080956, GACP 14081118, GACP14081522). Thailand, Chiang Mai Province, Mushroom Research Center, Coniferous rainforest, $19^{\circ} 20^{\prime} \mathrm{N}$ 98 $44^{\prime} \mathrm{E}$, elev. $770 \mathrm{~m}$, collection date 2014/06/21, collector LS Zha (GACP14062120, GACP14062122, GACP14062124).

Notes - Blume \& T. Nees described this species as a Polyporus rugosus on the basis of specimens from Java in 1826. Berkeley (1856) introduced a new species Porothelium rugosum from Brazil and Steyaert (1972) suggested Polyporus rugosus and Porothelium rugosum were similar species based on their morphological descriptions. Polyporus rugosus was transferred to Ganoderma (as G. rugosum) by Patouillard (1889). Patouillard (1894) took up the name Porothelium rugosum Berk. and changed it as Ganoderma sprucei Pat., since he considered that there were already an epithet called "rugosum" in Ganoderma. Torrend (1920) transferred G. sprucei Pat. to Amauroderma (A. rugosum). Porothelium rugosum was synonymized Berk. As Amauroderma sprucei (Pat.) Torrend (Furtado 1968). Thus, it was a problem whether P. rugosum Berk. (= G. sprucei Pat.) and $G$. rugosum (BI. \& Nees) Pat. were similar species. Torrend therefore continued to use 'sprucei', the earliest epithet available in Amauroderma. Considering the combination of Porothelium rugosum in Foraminispora the epithet is available. However, Costa-Rezende et al. (2017) proposed Foraminispora, a new genus to accommodate Porothelium rugosum (= Amauroderma sprucei) based on strong morphological and molecular data. According to Index Fungorum and MycoBank, A. rugosum (Blume \& T. Nees) Torrend is now a legitimized species characterized by mesopodal and often excentric, or often pleuropodal pileus with subglobose basidiospores. Amauroderma rude (Berk.) Torrend also has a light context and black pileus, but the pores are larger (2-3 per mm), and it is mainly distributed in Australia (Cunningham 1965). Ryvarden \& Johansen (1980) provided detailed description of this species and our collections agree well with that description and moreover, the descriptions provided by Chinese authors (Teng (1963, Tai 1979, Zhao et al. 1981, Zhao 1989, Bi et al. 1993, Teng 1996, Zhao \& Zhang, 2000). This species is a soil-inhabiting saprobe and usually found on the ground or attached to buried roots in hardwood forests (Baran De 1991) and widely distributed in the tropics, especially in South East Asia. In East Asia it is known from subtropical China, Japan, Taiwan, Northern Thailand, and Vietnam (Núñez \& Ryvarden 2000, Hapuarachchi et al. 2018b).

\section{Beneficial medicinal properties of Amauroderma}

Previously described members of Ganodermataceae have a long history of use to promote health and longevity in Asia (Hapuarachchi et al. 2017). Its species are widely researched, 

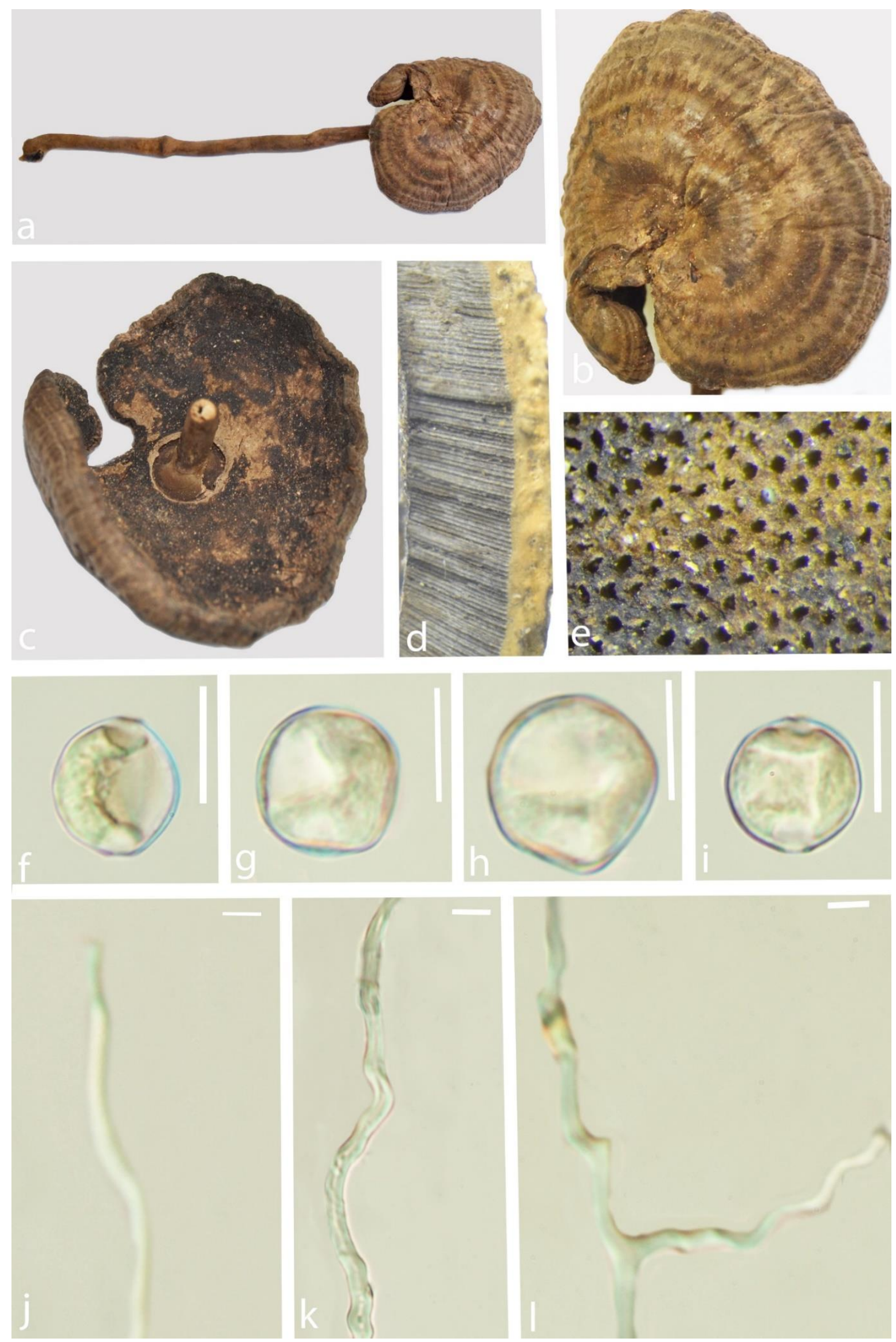

Fig. 3 - Amauroderma rugosum (GACP16072714). a, b Upper surface. c Lower surface. d Cut surface. e Pores in the lower surface $(5 \times)$. f-i Spores $(100 x)$. j Generative hyphae $(100 \times)$. k Skeletal hyphae (100x). 1 Binding hyphae (100x). Scale bars: $f-i=10 \mu \mathrm{m}, j-1=5 \mu \mathrm{m}$. 
because of their highly prized medicinal value with many chemical constituents with potential nutritional and therapeutic values (Hapuarachchi et al. 2016a, 2016b, Hapuarachchi et al. 2018a). Species in Amauroderma have been newly recognized as medicinal fungi (Chan et al. 2013, Jiao et al. 2013, Zhang et al. 2013). Amauroderma species are commonly known as the "epileptic child mushroom" or "Jia zhi" in China. It is traditionally used by the Chinese to reduce inflammation, to treat diuretic and indigestion, and to prevent cancer (Dai \& Yang 2008). The indigenous Temuan people in Malaysia believe this fungus has a power to heal epilepsy (Chang \& Lee 2004, Azliza et al. 2012). It was suggested that volatile components which may be present in the mushroom, may have contributed to the beneficial effects of this mushroom (Chan et al. 2015). In the following part of this paper, we discuss various bioactive compounds produced by Amauroderma species and its beneficial medicinal properties.

A new triterpenoid compound named amauroamoienin, together with 13 known compounds from ethyl acetate extracts of Amauroderma amoiensis (= A. rugosum) were discovered by Zhang et al. (2013). Amauroamoienin, (17R)-17-methylincisterol and jacareubin compounds exhibited acetyl cholinesterase inhibitory activities (Zhang et al. 2013). Purified Amaurocine, a purified novel protein from Amauroderma camerarium fermentations showed Amaurocine's activity against Trichomonas vaginalis isolates. It is the causative agent of Trichomoniasis, the most common nonviral sexual transfer disease worldwide. Furthermore, this protein demonstrated low toxicity towards human neutrophils and a pro-inflammatory character and Amaurocine may produce a synergic action being directly cytotoxic against the parasites and indirectly enhancing the host immune response, improving the protection from this mucosal pathogen (Duarte et al. 2016).

Twelve new compounds were isolated from the fruiting bodies of Amauroderma rude (diptoindonesin D, 6-deoxyjacareubin, jacareubin, 1H-indole-3- carboxylic acid, methyl 3,4-

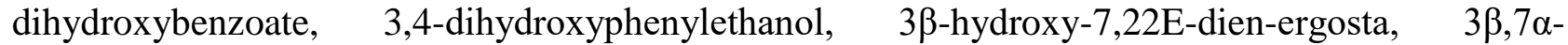

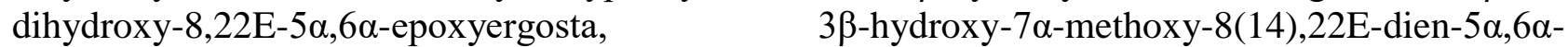
epoxyergosta, ergosterol $5 \alpha, 8 \alpha$ - peroxide, $3 \beta-5 \beta-8 \beta$-trihydroxy-6,22E-ergosta, and $3 \beta, 5 \alpha-6 \beta-$ trihydroxy-7,22E-dien-ergosta). Among them 6-deoxyjacareubin and jacareubin exhibited the cytotoxic activities against HL-60, SMMC-7721, A-549, MCF-7, and SW-480 cell lines and 3 $\beta$ hydroxy-7 $\alpha$-methoxy-8(14), 22E-dien-5 $\alpha, 6 \alpha$-epoxyergosta showed the cytotoxic activities against HL-60, MCF-7, and SW-480 cell lines (Chen et al. 2016). Low concentrations of water extracts of A. rude could inhibit breast cancer cell survival and induce apoptosis Jiao et al. (2013). Pan et al. 2017) revealed that oral administration of $A$. rude extract daily for 90 days does not cause any subchronic toxicity of mice. Li et al. (2015) found, ergosterol purified from A. rude induced cancer cell death in vivo. Furthermore ergosterol-mediated suppression of breast cancer cell viability occurred through apoptosis and that ergosterol up-regulated expression of the tumor suppressor Foxo3. They suggested ergosterol is the main anti-cancer ingredient in $A$. rude, which activated the apoptotic signal pathway. Pan et al. (2015) showed crude $A$. rude extract under in vitro experiments showed the capacities of spleen lymphocytes, macrophages, and natural killer cells were increased in tumor growth and in vivo experiments showed the extract increased macrophage metabolism, lymphocyte proliferation, and antibody production. Furthermore, the partially purified product stimulated the secretion of cytokines in vitro, and in vivo and in turn decreased tumor growth rates. The active compound was purified and identified as polysaccharide F212 and it had the highest activity in increasing lymphocyte proliferation. Wang \& Qi (2016) concluded that the extract of $A$. rude - roots of Lentinus solid fermentation compounds possessed antioxidant activity. Ten chemical compounds were isolated from the fruiting bodies of $A$. subresinosum including 2 new ones named amaurosubresin and erythro $(23,24)-5 \alpha, 6 \alpha$, epoxyergosta-8-ene-7-one-3 $\beta, 23$-diol. The bioassay of inhibitory activity against acetyl cholinesterase (AChE) of two new isolates exhibited definite inhibitory activity (Wang et al. 2016).

The presence of carbohydrates, proteins, dietary fibre, phosphorus, potassium, and sodium in mycelia of Amauroderma rugosum has been confirmed by Chan et al. (2013). Furthermore, A. rugosum Ethyl acetate extract exhibited the highest total phenolic content and the strongest antioxidant activity based on 2,2-diphenyl-1-picrylhydrazyl (DPPH) and 2,2'-azino-bis(3- 
ethylbenzothiazoline-6-sulphonic acid) (ABTS) assays. Hexane extracts showed dose-dependent inhibition of NO production in LPS-stimulated RAW264.7 cells and NO radical scavenging activity. In addition Gas chromatographic analysis of Hexane extracts showed the presence of ethyl linoleate and ergosterol, compounds with known anti-inflammatory properties. Hence, mycelia extracts of $A$. rugosum have the potential to serve as a therapeutic agent or adjuvant in the management of inflammatory disorders Chan et al. 2013). Wild and domesticated basidiocarps of A. rugosum possessed anti-oxidant activity and in vitro anti-inflammatory properties. Ethanolic extractions of wild and domesticated basidiocarps inhibited downstream inflammatory mediators (TNF- $\alpha$ and NO) and induced anti-inflammatory cytokine IL-10 production. No inhibitory effects shown on upstream nuclear translocation of NF- $\mathrm{BB}$ p65. Furthermore, both wild and domesticated ethanolic extractions exhibited antioxidant activity and attenuation of proinflammatory mediators (Chan et al. 2015).

Amauroderma rugosum showed antimicrobial activity against Staphylococcus aureus, S. pyogenes, Pseudomonas aeruginos, Escherichia coli and Clostridium difficile (Liew et al. 2015). Methanol and cold and hot water extracts of the freeze-dried mycelial culture of A. rugosum exhibited no or little cytotoxic effect against the MCF-7 and A-549 cell lines. Furthermore, oral administration of a single dose of mycelial powder $(2000 \mathrm{mg} / \mathrm{kg})$ to Sprague-Dawley rats had no adverse effect on the growth rate or hematological and clinical biochemical parameters and not induce any pathological changes in the organs of the tested animals (Fung et al. 2017). Oleateinduced HepG2 cells treated with A. rugosum ethyl acetate (EA) extract greatly decreased intracellular and secreted total triglyceride (TG) and total cholesterol (TC) compared with other extracts. Hence, the A. rugosum EA extract is a good source of lipid-ameliorating agents in the management of dyslipidemia (Seng et al. 2017a). The semipolar ethyl acetate (EA) fraction of $A$. rugosum demonstrated good antioxidant capacity based on total phenolic content, 2, 2-diphenyl-1picrylhydrazyl free radical scavenging, ferrous ion-chelating ability, cupric ion-reducing antioxidant capacity, and lipid peroxidation assays. The EA fraction also showed the strongest inhibitory effect on $\mathrm{Cu} 2+$-induced LDL oxidation via thiobarbituric acid reactive substances formation and HMG-CoA reductase activity. Moreover, the phenolic compounds (4 benzoic acid derivatives, 3 flavonoids, 1 cinnamic acid, 1 hexahydroxydiphenic acid dilactone, and 1 xanthone derivative), play pivotal roles in arresting the physiopathogenesis of atherosclerosis and attenuating the risk of cardiovascular events occurring (Seng et al. 2017b).

Research on various metabolic activities of Amauroderma have been performed in vitro studies. However, there has been no report of in vivo studies and human trials using Amauroderma as a direct control agent diseases. Hence, Amauroderma and related products can be used as a therapeutic drug if more direct scientific evidence are available in the future.

\section{Conclusion}

Macroscopic, microscopic, and molecular data all confirm that the Amauroderma collections from Laos belong to Amauroderma pressuii and A. rugosum. This is the first discovery of these two species in Laos. The studies of more collections of these species are needed to better estimate the variability of these taxa. Some in vitro studies of medicinal properties of Amauroderma appear to be promising, but careful investigation and accurate scientific evidences needed for establishing the safe and efficient use of Amauroderma. Experimental, epidemiological, and clinical studies should be carried out on identification of the molecular targets and investigate the association between Amauroderma intake and disease risk.

\section{Acknowledgements}

This work was financed by the Science and Technology Foundation of Guizhou Province (No. [2017]2511-1), and the Science Research Foundation of Guizhou University (No. 201309). Kalani K. Hapuarachchi is grateful to Hansika Perera and Ishani Goonasekara for their valuable comments and suggestions. 


\section{References}

Azliza MA, Ong HC, Vikineswary S, Noorlidah A et al. 2012 - Ethno-medicinal resources used by the Temuan in Ulu Kuang Village. Studies on Ethno-Medicine 6(1), 17-22. doi.org/10.1080/09735070.2012.11886415

Baran De A. 1991 - Distribution of Aphyllophorales in India II. Amauroderma rugosum, Amylosporus campbellii and Scytinopogon angulisporus. Acta Botanica Croatica 50, 55-58.

Berkeley MJ. 1856 - Decades of fungi. Decades LIX - LX. Rio Negro fungi. Hooker's Journal of Botany and Kew Garden Miscellany 8, 233-241.

Bi ZS, Zheng G, Li TH. 1993 - The Macro fungus Flora of China's Guangdong Province, 119.

Cao Y, Wu SH, Dai YC. 2012 - Species clarification of the prize medicinal Ganoderma mushroom “Lingzhi'”. Fungal Diversity 56, 49-62. doi.org/10.1007/s13225-012-0178-5

Chan PM, Kanagasabapathy G, Tan YS, Sabaratnam V et al. 2013 - Amauroderma rugosum (Blume \& T. Nees) Torrend: Nutritional Composition and Antioxidant and Potential AntiInflammatory Properties. Evidence-Based Complementary and Alternative Medicine 2013. doi.org/10.1155/2013/304713.

Chan PM, Tan YS, Chua KH, Sabaratnam V et al. 2015 - Attenuation of inflammatory mediators (TNF- $\alpha$ and nitric oxide) and up-regulation of IL-10 by wild and domesticated basidiocarps of Amauroderma rugosum (Blume \& T. Nees) Torrend in LPS-stimulated RAW264. 7 cells. PloS one 10(10): e0139593. doi.org/10.1371/journal.pone.0139593

Chandrasrikul A, Suwanarit P, Sangwanit U, Lumyong S et al. 2011 - Checklist of mushrooms (Basidiomycetes) in Thailand Office of Natural Resources and Environmental Policy and Planning, Bangkok, Thailand 448.

Chang YS, Lee SS. 2004 - Utilisation of macrofungi species in Malaysia. Fungal Diversity, 15, 1522.

Chen YL, Ma QY, Huang SZ, Dai HF et al. 2016 - Chemical constituents from fruiting bodies of Amauroderma rude. 47, 881-885. doi.org/10.7501/j.issn.0253-2670.2016.06.004.

Cooke MC. 1886 - Praecursores ad Monographia Polypororum. Grevillea 15, 19-27.

Costa-Rezende DH, Gugliotta AM, Goes-Neto A, Reck MA et al. 2016 - Amauroderma calcitum sp. nov. and notes on taxonomy and distribution of Amauroderma species (Ganodermataceae). Phytotaxa 244, 101-124. doi.org/10.11646/phytotaxa.244.2.1

Costa-Rezende DH, Robledo GL, Goes-Neto A, Reck MA et al. 2017 - Morphological reassessment and molecular phylogenetic analyses of Amauroderma s.lat. raised new perspectives in the generic classification of the Ganodermataceae family. Persoonia 39, 254 269. doi: 10.3767/persoonia.2017.39.10

Cunningham GH. 1965 - Polyporaceae of New Zealand. N Z Department of Scientific Industrial Research Bulletin 164, 1-304.

Dai YC, Cui BK, Yuan HS, He SH et al. 2011 - Wood-inhabiting fungi in southern China. 4. Polypores from Hainan Province. Annales Botanici Fennici 48, 219-231. doi.org/10.5735/085.048.0302

Dai YC, Cui BK, Yuan HS, Li BD. 2007 - Pathogenic wood-decaying fungi in China. Forest Pathology 37, 105-120. doi.org/10.1111/j.1439-0329.2007.00485.x

Dai YC, Yang ZL. 2008 - A revised checklist of medicinal fungi in China. Mycosystema 27, 801824. doi.org/10.1111/j.1439-0329.2007.00485.X

Dai YC, Yang ZL, Cui BK, Yu CJ et al. 2009 - Species diversity and utilization of medicinal mushrooms and fungi in China. International Journal of Medicinal Mushrooms 11, 287-302. doi.org/10.1615/IntJMedMushr.v11.i3.80

Duarte M, Seixas A, de Carvalho MP, Tasca T et al. 2016 - Amaurocine: Anti-Trichomonas vaginalis protein produced by the basidiomycete Amauroderma camerarium. Experimental parasitology 161, 6- 1. doi.org/10.1016/j.exppara.2015.12.012

Fung SY, Tan NH, Lee SS, Tan YS et al. 2017 - Acute Toxicity Study and the In Vitro Cytotoxicity of a Black Lingzhi Medicinal Mushroom, Amauroderma rugosum 
(Agaricomycetes) from Malaysia. International journal of medicinal mushrooms. 9(12), 1093-1099. doi: 10.1615/IntJMedMushrooms.2017024550

Furtado JS. 1968 - Revisão do gênero Amauroderma (Polyporaceae). Estudos baseados nas microestruturas do basidiocarpo. PhD Thesis, Universidade de São Paulo, São Paulo (Brazil) 384.

Furtado JS. 1981 - Taxonomy of Amauroderma (Basidiomycetes, Polyporaceae). Memoirs of the New York Botanical Garden 34, 1-109.

Gomes-Silva AC, Baltazar JM, Ryvarden L, Gibertoni TB. 2010 - Amauroderma calcigenum (Ganodermataceae, Basidiomycota) and its presumed synonym A. partitum. Nova Hedwigia 1, 90(3-4), 449-455. doi.org/10.1127/0029-5035/2010/0090-0449

Gomes-Silva AC, Lima-Júnior N, Malosso E, Ryvarden L et al. 2015 - Delimitation of taxa in Amauroderma (Ganodermataceae, Polyporales) based in morphology and molecular phylogeny of Brazilian specimens. Phytotaxa 227, 201-228. doi.org/10.11646/phytotaxa.227.3.1

Hall TA. 1999 - BioEdit: a user-friendly biological sequence alignment editor and analysis program for Windows 95/98/NT. In: Nucleic Acids Symposium Series. 41, 95-98. doi.org/10.12691/ajmr-2-6-8

Hapuarachchi KK, Cheng CR, Wen TC, Jeewon R et al. 2017 - Mycosphere Essays 20: Therapeutic potential of Ganoderma species: Insights into its use as traditional medicine. Mycosphere 8, 1653-1694. doi: 10.5943/mycosphere/8/10/5

Hapuarachchi KK, Elkhateeb WA, Karunarathna SC, Cheng CR et al. 2018a - Current status of global Ganoderma cultivation, products, industry and market. Mycosphere 9(5), 1025-1052. doi 10.5943/mycosphere/9/5/6

Hapuarachchi KK, Karunarathna SC, Raspé O, De Silva KHWL et al. 2018b - High diversity of Ganoderma and Amauroderma (Ganodermataceae, Polyporales) in Hainan Island, China. Mycosphere 9(5), 931-982. doi 10.5943/mycosphere/9/5/1

Hapuarachchi KK, Wen TC, Deng CY, Kang JC et al. 2015 - Mycosphere Essays 1: Taxonomic confusion in the Ganoderma lucidum species complex. Mycosphere 6 (5), 542-559. doi 10.5943/mycosphere/6/5/4

Hapuarachchi KK, Wen TC, Jeewon R, Wu XL et al. 2016a - Mycosphere Essays 7: Ganoderma lucidum - are the beneficial anti-cancer properties substantiated? Mycosphere 7 (3), 305-332. doi: 10.5943/mycosphere/7/3/6

Hapuarachchi KK, Wen TC, Jeewon R, Wu XL et al. 2016b - Mycosphere Essays 15: Ganoderma lucidum are the beneficial medical properties substantiated? Mycosphere 7, 687-715. doi: 10.5943/mycosphere/7/6/1

Hennings P. 1891 - Fungi africani. Botanische Jahrbücher für Systematik Pflanzengeschichte und Pflanzengeographie 14, 337-373

Index Fungorum. 2018 - Available from: http://www.indexfungorum.org/Names/Names.asp

Jayasiri SC, Hyde KD, Ariyawansa HA, Bhat J et al. 2015 - The Faces of Fungi database: fungal names linked with morphology, phylogeny and human impacts. Fungal Diversity 74, 3-18. doi.org/10.1007/s 13225-015-0351-8

Jiao C, Xie YZ, Yang X, Li H et al. 2013 - Anticancer Activity of Amauroderma rude. PLoS ONE 8(6): e66504. doi:10.1371/journal.pone.0066504

Katoh K, Standley DM. 2013 - MAFFT multiple sequence alignment software version 7: improvements in performance and usability. Molecular biology and evolution 30(4), 772 780.

Kornerup A, Wanscher JH. 1978 - Eyre Methuen, London, Methuen handbook of color.

Li MJ, Yuan HS. 2015 - Type studies on Amauroderma species described by J.D. Zhao et al. and the phylogeny of species in China. Mycotaxon 130, 79-89. doi.org/10.5248/130.79

Liew GM, Khong HY, Kutoi CJ, Sayok AK. 2015 - Phytochemical screening, antimicrobial and antioxidant activities of selected fungi from Mount Singai, Sarawak, Malaysia. International Journal of Research Studies in Biosciences 3(1), 191-197. 
Miller RE, Blair PD. 2009 - Input-output analysis: foundations and extensions. Cambridge University Press. https://doi.org/10.1017/CBO9780511626982.

Nilsson RH, Tedersoo L, Abarenkov K. 2012 - Five simple guidelines for establishing basic authenticity and reliability of newly generated fungal ITS sequences. MycoKeys 4:37-63. https://doi.org/10.3897/mycokeys.4.3606

Núñez M, Ryvarden L. 2000 - East Asian polypores. Synopsis Fungorum 13, 1-168.

Nylander JAA. 2004 - MrModeltest v2.2. Program distributed by the author: 2. Evolutionary Biology Centre, Uppsala University 1-2.

Pan H, Han Y, Huang J, Yu X et al. 2015 - Purification and identification of a polysaccharide from medicinal mushroom Amauroderma rude with immunomodulatory activity and inhibitory effect on tumor growth. Oncotarget 10 6(19), 17777-17791. doi.org/10.18632/oncotarget.4397

Pan H, Zhang Y, Liang B, Zhao X et al. 2017 - Acute and Subchronic Toxicity of Dusky-Skinned Mushroom, Amauroderma rude (Agaricomycetes). International journal of medicinal mushrooms 19(8), 727-735. 10.1615/IntJMedMushrooms.2017021269.

Patouillard NT. 1889 - Le genre Ganoderma. Bulletin trimestriel de la Société mycologique de France 5, 64-80.

Patouillard NT. 1894 - Espèces critiques d'Hyménomycètes. Bulletin de la Société Mycologique de France 10(2), 75-81.

Quang DN, Nga TT, Tham LX. 2011 - Chemical Composition of Vietnamese Black Lingzhi Amauroderma Subresinosum Murr. Research Journal of Phytochemistry 5(4), 216-221. doi: 10.3923/rjphyto.2011.216.221

Rambaut A, Suchard MA, Xie D, Drummond AJ. 2013 - Tracer version 1.6. University of Edinburgh. [Online]. http://tree.bio.ed.ac.uk/software/tracer [Accessed on 19.11.2016]

Rambaut A. 2012 - FigTree version 1.4.0. http://tree.bio.ed.ac.uk/software/figtree/

Richter C, Wittstein K, Kirk MP, Stadler M. 2015 - An assessment of the taxonomy and chemotaxonomy of Ganoderma. Fungal Diversity 71. doi: 10.1007/s13225-014-0313-6 71

Ryvarden L. 2004 - Neotropical polypores Part 1. Synopsis Fungorum. 19, 1-229.

Ryvarden L, Johansen I. 1980 - A preliminary polypores flora of East Africa. Fungi flora, Oslo 1636.

Seng CK, Abdullah N, Aminudin N. 2017a - Lipid Modulating Effect of Black Lingzhi Medicinal Mushroom, Amauroderma rugosum (Agaricomycetes) on Oleate-Induced Human Hepatocellular Liver Carcinoma Cells. International journal of medicinal mushrooms 19(12), 1101-1111. 10.1615/IntJMedMushrooms.2017024589

Seng CK, Abdullah N, Aminudin N. 2017b - Antioxidative and Inhibitory Effects of the Fruiting Body of Black Lingzhi Mushroom, Amauroderma rugosum (Agaricomycetes), on LDL Oxidation and HMG-CoA Reductase Activity. International journal of medicinal mushrooms. 19(9), 797-807. doi: 10.1615/IntJMedMushrooms.2017024374

Song J, Xing JH, Decock C, HE XL et al. 2016 - Molecular phylogeny and morphology reveal a new species of Amauroderma (Basidiomycota) from China. Phytotaxa 260, 47-56. doi: http://dx.doi.org/10.11646/phytotaxa.260.1.5

Stamatakis A. 2014 - RAxML version 8: a tool for phylogenetic analysis and post-analysis of large phylogenies. Bioinformatics 30(9), 1312-1313. https://doi.org/10.1093/ bioinformatics/ btu033

Steyaert RL. 1972 - Species of Ganoderma and related genera mainly of the Bogor and Leiden Herbaria. Persoonia 7(1), 55-118.

Tai FL. 1979 - Sylloge Fungorum Sinicorum. Beijing: Science Press 1527. (in Chinese)

Teng SC. 1936 - Additional fungi from China III. Sinensia 7, 529-569.

Teng SC. 1963 - Fungi of China. Beijing: Science Press 808. (in Chinese)

Teng SC. 1996 - Fungi of China. Mycotax on Ithaca 1-586.

Thaung MM. 2007 - A preliminary survey of macromycetes in Burma. Australasian mycologist 26(1), 16-36. 
Torrend C. 1920 - Les polyporacées du Bresil. Broteria, série botânica 18, 121-142.

Wang Q, Qi Y. 2016 - Antioxidant activity of Amauroderma rudis-roots of Lentinus solid fermentation compounds. Journal of Food Safety and Quality 7(2), 682-685.

Wang Q, Wang YG, Ma QY, Huang SZ et al. 2016 - Chemical constituents from the fruiting bodies of Amauroderma subresinosum. Journal of Asian natural products research 1, 18(11), 1030-1035.

White TJ, Bruns T, Lee S, Taylor J. 1990 - Amplification and direct sequencing of fungal ribosomal RNA genes for phylogenetics. In: Innis, MA, Gelfand DH, Sninsky JJ. \& White, T.J. (eds) PCR protocols: a guide to methods and applications. San Diego.

Wu XL, Dai YC 2005 - Coloured illustrations of 'Ganodermataceae' of China. Science Press.

Zhang SS, Ma QY, Zou XS, Dai HF et al. 2013 - Chemical constituents from the fungus Amauroderma amoiensis and their in vitro acetylcholinesterase inhibitory activities. Planta Medica 79(01), 87-91. doi: 10.1055/s-0032-1327951

Zhao JD. 1989 - The Ganodermataceae in China. Bibliotheca Mycologica 132. Berlin: J. Cramer 176.

Zhao JD, Hsu LW, Zhang XQ. 1979 - Taxonomic studies on the subfamily Ganodermoideae of China (in Chinese). Acta Mycologica Sinica 19, 265-279.

Zhao JD, Xu LW, Zhang XQ. 1981 - Ganodermoideae of China. Beijing: Science Press, 1-106. (in Chinese)

Zhao JD, Zhang XQ. 1987 - Taxonomic studies on Ganodermataceae of China VIII. Acta Mycologica Sinica 6, 199-210.

Zhao JD, Zhang XQ. 2000 - Flora Fungorum Sinicorum 18: Ganodermataceae. Beijing: Science Press, 204. (in Chinese)

Zhou LW, Cao Y, Wu SH, Vlasak J et al. 2015 - Global diversity of the Ganoderma lucidum complex (Ganodermataceae, Polyporales) inferred from morphology and multilocus phylogeny. Photochemistry 114, 7-15. Doi: 10.1016/j.phytochem.2014.09.023 